\title{
THE WIDTH OF A FAIRWAY - COMPARISON OF MODELS
}

\section{SZEROKOŚĆ TORU WODNEGO - PORÓWNANIE MODELI}

\author{
Stanisław Gucma \\ Maritime University of Szczecin, Institute Marine Traffic Engineering, \\ Wały Chrobrego str. 1/2, 70-500 Szczecin, Poland \\ E-mail: s.gucma@am.szczecin.pl
}

\begin{abstract}
This article presents probabilistic and deterministic methods of safe waterway width assessment. The models were used to obtain optimal parameters of different type waterways. An analysis of results will be conducted to determine possible applications of the proposed methods.
\end{abstract}

Key words: marine traffic engineering, waterways, fairway width

Streszczenie: $W$ artykule zostana zaprezentowane modele probabilistyczne $i$ deterministyczne określenia bezpiecznej szerokości dróg wodnych. Modele te zastosowano do określenia bezpiecznej szerokości dróg wodnych różnego typu. $W$ oparciu o przeprowadzone badania zostanie przeprowadzona analiza możliwości zastosowania tych modeli dla różnego typu dróg wodnych.

Stowa kluczowe: inżynieria ruchu morskiego, drogi wodne, szerokość toru wodnego 


\section{Introduction}

Performing a given manoeuvre in port waters is related with a risk of ship's contact with the ground. This undesired event results in losses which take various forms: sometimes disastrous, such as damage to the ship and port infrastructure, loss of life or environmental pollution.

For a manoeuvre in port areas to be safe, it has to satisfy the condition of safe depth that can be written in the following form [3]:

$$
h(x, y, t) \geq T(x, y, t)+\Delta(x, y, t)
$$

where

$h(x, y, t)-$ depth of water at the point with coordinates $(x, y)$ at the noment $t$;

$T(x, y, t)$ - ship draft at the point $(x, y)$ at the moment $t$;

$\Delta(x, y, t$ - underkeel clearance at the point $(x, y)$ at the moment $t$.

The ship can safely manoeuvre only in the area that satisfies the above condition of required depth. Such area is called the available navigational area. While the ship is manoeuvring within the available navigational area, it covers a specific path determined by its subsequent positions. The parameters of this path depend on a number of factors. The path is known as the safe manoeuvring area.

The condition for performing a safe manoeuvre is as follows [3]:

$$
\mathbf{d}_{\mathrm{ijk}} \subset \mathbf{D}(\mathrm{t})
$$

where

$\mathbf{d}_{\mathrm{ijk}}$ - safe manoeuvring area of the $i$-th ship, performing the $j$-th manoeuvre in the $k$-th navigational conditions,

$\mathbf{D}(\mathrm{t})$ - available navigational area (set of area points $p(x, y)$ meeting the available depth condition at the moment $t$ ).

Navigational conditions are determined by hydrometeorological conditions and aids to navigation deployed in the area under consideration.

Taking into account the required underwater clearance and the safe manoeuvring area, we can write the basic condition of navigational safety in this form [3]: 


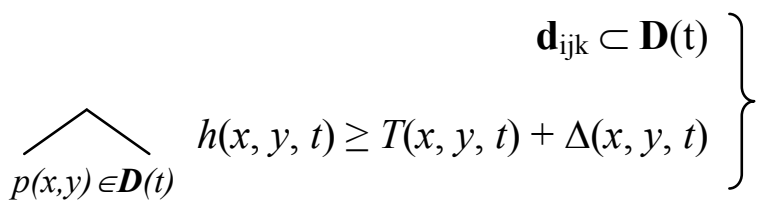

The sets of points in the available navigational area $\mathbf{D}(\mathrm{t})$, as well as the safe manoeuvring area $\mathbf{d}_{\mathrm{ijk}}$ can be identified as areas with defined linear parameters. On various types of waterway the basic linear parameter critical for the safety of manoeuvre is its width. In this connection the condition of safe manoeuvre performance can be transformed to this form:

$$
D(t)_{i j k} \geq d_{i j k}
$$

where

$$
\begin{aligned}
D(t)_{i j k}- & \text { width of the available navigational area at the moment } t \\
& \text { (area available for navigation of the } i \text {-th ship performing the } \\
& j \text {-th manewr in } k \text {-th navigational conditions); } \\
d_{i j k}- & \text { width of safe manoeuvring area of the } i \text {-th, performing the } j \text { - } \\
& \text { th manewr in } k \text {-th navigational conditions. }
\end{aligned}
$$

The width of safe manoeuvring area can be determined using either of the two models of ship movement in restricted areas:

- deterministic model,

- probabilistic model.

In the deterministic model the width of safe manoeuvring area is a variable depending on ship $(i)$ parameters, performing a manoeuvre $(j)$ and the prevailing navigational conditions $(k)$ :

$$
d_{i j k}=\int(i, j, k)
$$

In the probabilistic model the width of safe manoeuvring area is a random variable. In descriptions of this parameter the normal distribution is generally adopted as it fits well the reality (Fig. 1). The distribution of distances of the extreme points of the manoeuvring area to the fairway centre can be expressed as follows [1]:

$$
\begin{aligned}
& d_{I}(y)=\frac{1}{\delta_{I} \sqrt{2 \Pi}} e^{-\frac{\left(y-m_{I}\right)^{2}}{2 \delta_{I}^{2}}} \\
& d_{p}(y)=\frac{1}{\delta_{p} \sqrt{2 \Pi}} e^{-\frac{\left(y-m_{p}\right)^{2}}{2 \delta_{p}^{2}}}
\end{aligned}
$$


where

$$
\begin{aligned}
d_{l}(y) ; d_{p}(y)- & \text { distance from the fairway centre to the port and } \\
& \text { starboard limits of the manoeuvring area, } \\
m_{l} ; \delta_{l} \quad & \text { mean and standard deviation of the distance between } \\
& \text { fairway centre and port side limit of the manoeuvring } \\
& \text { area, } \\
m_{p} ; \delta_{p} \quad- & \text { mean and standard deviation of the distance between } \\
& \text { fairway centre and starboard side limit of the } \\
& \text { manoeuvring area. }
\end{aligned}
$$

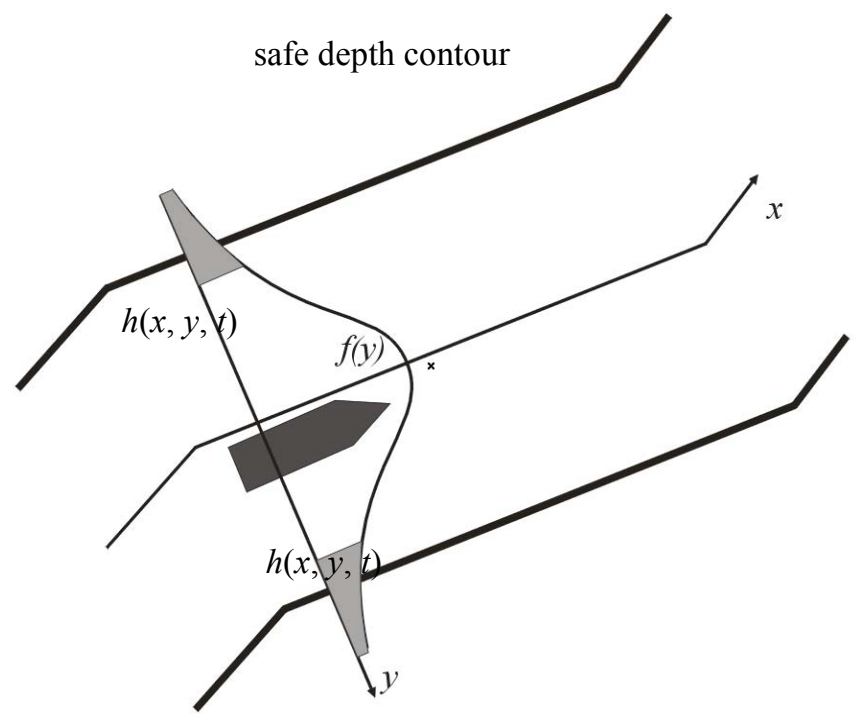

Fig. 1 The width of safe manoeuvring area in the probabilistic model

\section{Methods of fairway width determination}

Methods of safe fairway width determination may be divided depending on how the solution is obtained: analytical (theoretical and empirical) and simulation $[2,3]$.

In the analytical model the width of safe manoeuvring area along a straight fairway section can be described as follows (Fig. 2):

$$
d=2\left(d_{n}+d_{m}\right)+d_{r}
$$


while

$$
d_{m}=d_{m 1}+d_{m 2}
$$

where

$d_{n}$ - navigational component - manoeuvring area width (swepth path) $[\mathrm{m}]$,

$d_{m}$ - manoeuvring component - manoeuvring area width (swept path) $[\mathrm{m}]$,

$d_{m 1}$ - width of the path covered by the trajectory of ship's gravity centre during yawing,

$d_{m 2}$ - width of the path covered by the ship's hull moving outside the movement trajectory.

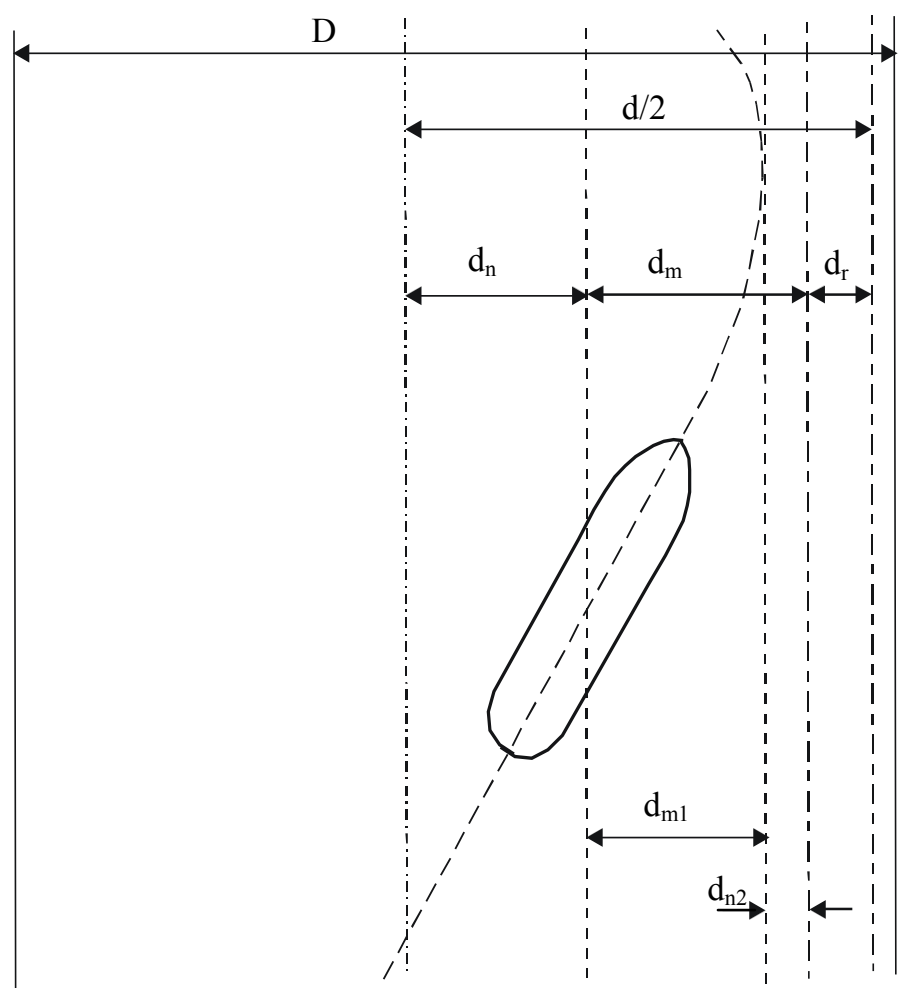

Fig. 2 Components of the swept path width 
Theoretical methods include one with three components as developed by this author [2], in which elements of ship movement are described using deterministic models, while positioning elements are defined with the use of the probabilistic model.

The following are empirical methods based only on deterministic models:

- Panama Canal method,

- PIANC method,

- Canadian method,

- USACE method.

Empirical methods built on deterministic models define a constant value of safe fairway width for preset navigational conditions assuming that this is the width ensuring manoeuvring safety in specified conditions. This width is determined by real methods, usually expert or statistical ones, where the definition of safety has various interpretations in the assumptions of each method.

The empirical method based on deterministic models used for ship movement elements and on the probabilistic model utilized in relation to positioning elements is the method of Marine Traffic Engineering (MTE) developed by this author [2].

Computer simulation consists of a number of actions aimed at creating a simulation model and making tests on it. At present simulation methods are frequently used in research within marine traffic engineering due to such advantages as:

- universality of research, which allows to obtain results of varying accuracy, depending on how the problem is formulated; this accuracy is mainly determined by the application of the simulation model of specific complexity;

- relatively low costs of research.

Simulation methods make up the most important group of research methods for the determination of safe manoeuvring area parameters.

Time and type of ship model control are basic criteria for the classification of simulation methods used in system testing within marine traffic engineering. The criterion of time in which simulation is made yields two basic methods:

- real time simulation (RTS);

- fast time simulation (FTS). 
There are two types of simulation in terms of ship movement control, in which models used are:

- non-autonomous,

- autonomous.

In non-autonomous simulation models the ship is controlled by the human (navigator), while autonomous models make use of a mathematical model of the navigator for ship control.

If we compare the simulation methods used in marine traffic engineering, we will find that real time methods utilizing non-autonomous ship movement models have a number of advantages:

- good verification results are obtained in case of complex manoeuvres;

- navigator's qualifications and their changeability in the process of ship conduct can be taken into account;

- taking into consideration the parameters of user interface in various navigational systems;

- possibility of conducting various types of navigational and manoeuvring training.

The main inconvenience of these methods is relatively high time consumption.

On the other hand, fast time simulation methods using autonomous models of ship movement are these:

- possibility of performing many simulated manoeuvres (passages along the examined waterway) in a short time;

- possibility of testing several variants;

- low cost of research.

Among weak points of these methods is poor verification of complex manoeuvres.

The width of a safe manoeuvring area can also be determined by generalizing the results of simulation research. This method, on the basis of previously performed simulated experiments including various ships, manoeuvres and navigational conditions, allows to determine the parameters of a safe manoeuvring area [3]. Using this method, we can determine the width of a safe manoeuvring area at a preset confidence level in the form of the regression equation [1]:

$$
d(1-\alpha)=b_{o}+b_{B} B+b_{D} D+b_{L} L_{C}+b_{M} M+b_{W} W+b_{P} P[\mathrm{~m}]
$$


where

$B$ - ship's breadth [m],

$D$ - available navigational area $[\mathrm{m}]$,

$L_{C}$ - ship's length overall [m],

$M$ - coefficient of manoeuvrability,

$W$ - wind speed $[\mathrm{m} / \mathrm{s}]$,

$P \quad$ - current coefficient.

\section{Analysis of the results of safe fairway width tests}

A number of real and simulation tests were performed to determine the safe width of fairways. The results of these tests, performed for various ships and areas, have unequivocally verified the autonomous simulation methods developed at the Institute of Marine Traffic Engineering, Maritime University of Szczecin [2, 3].

Comparing the results of calculated safe fairway width, determined by methods using deterministic models for various ships and waterways, we can draw the following conclusions:

1. Empirical methods using deterministic models used for tests in straight fairway sections yield similar results for the ships examined:

- $\quad$ sea-going ferry: $L_{C}=155 \mathrm{~m}, B=21.6 \mathrm{~m} \mathrm{[4]}$

$$
d=2.8 B \div 3.3 B
$$

where $B$-ship's breadth

- container ships: $L_{C}=175 \mathrm{~m} \div 210 \mathrm{~m}, B=25 \mathrm{~m} \div 30 \mathrm{~m} \mathrm{[5]}$

$$
d=2.9 B \div 3.0 B
$$

- cruise ships: $L_{C}=220 \mathrm{~m} \div 260 \mathrm{~m}, B=28 \mathrm{~m} \div 33 \mathrm{~m} \mathrm{[5]}$

$$
d=3.1 B \div 3.2 B
$$

These results can be verified against the data obtained from real tests and simulation ones $[1,4]$. 
2. In fairway bends empirical methods using deterministic models have a substantial scatter of results up to $80 \%$ :

- $\quad$ sea-going ferry: $L_{C}=155 \mathrm{~m}, B=21.6 \mathrm{~m}[4]$

$$
d=2.8 B \div 4.9 B
$$

- container ships: $L_{C}=175 \mathrm{~m} \div 210 \mathrm{~m}, B=25 \mathrm{~m} \div 30 \mathrm{~m} \mathrm{[5]}$

$$
d=3.3 B \div 5.1 B
$$

- cruise ships: $L_{C}=220 \mathrm{~m} \div 260 \mathrm{~m}, B=28 \mathrm{~m} \div 33 \mathrm{~m} \mathrm{[5]}$

$$
d=3.44 B \div 5.9 B
$$

The Canadian, USACE and PIANC methods yield lowered results in comparison with the results obtained from real and simulation methods.

3. In transitory sections before and after a bend in the fairway, of the same length as the ship, the width of the safe manoeuvring area is larger by about $15 \%$ than the width in straight fairway sections.

\section{References}

1. Gucma L.: Modelowanie czynników ryzyka zderzenia jednostek pływajacych $z$ konstrukcjami portowymi $i$ petnomorskimi. Praca habilitacyjna. Studia nr 44, Akademia Morska w Szczecinie, Szczecin 2005.

2. Gucma S.: Inżynieria ruchu morskiego. Monografia, Wydawnictwo: "Okrętownictwo i Żegluga", Gdańsk 2001.

3. Gucma S., Gucma L., Zalewski P.: Symulacyjne metody badań $w$ inżynierii ruchu morskiego. Monografia pod redakcją Stanisława Gucmy. Wydawnictwo Naukowe Akademii Morskiej w Szczecinie, Szczecin 2008.

4. Montewka J.: Określenie bezpiecznego akwenu manewrowego statku przy zastosowaniu badań rzeczywistych - weryfikacja metod symulacyjnych oraz analitycznych. Rozprawa doktorska, Akademia Morska w Szczecinie, Szczecin 2008. 
5. Praca zbiorowa: Określenie docelowych bezpiecznych parametrów toru wodnego Świnoujście-Szczecin (praca naukowo-badawcza). Akademia Morska w Szczecinie, Szczecin 2008.

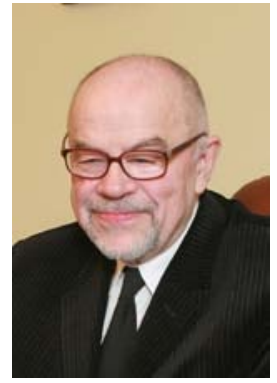

Stanislaw Gucma Professor, Master Mariner, is professor at the Maritime University of Szczecin. He is the creator of the new scientific discipline in Poland: marine traffic engineering. An author of ten books and over 160 scientific publications on the subject. Professor Gucma has been in charge of more than 100 research projects. Most of them were implemented in Poland and EU countries. Some projects were related to the largest maritime investments in Poland. A member of the Transport Committee of the Polish Academy of Sciences (PAN), Academy of Engineering in Poland and the Transport Committee of Russia. 